

\title{
Lean Healthcare Practices Improve the Patient Performance in Public Hospitals
}

\section{Maria Shazwina Tajudin, Nurul Fadly Habidin}

To Link this Article: http://dx.doi.org/10.6007/IJARBSS/v10-i7/7608
DOI:10.6007/IJARBSS/v10-i7/7608

Received: 02 April 2020, Revised: 04 May 2020, Accepted: 20 June 2020

Published Online: 28 July 2020

In-Text Citation: (Tajudin \& Habidin, 2020)

To Cite this Article: Tajudin, M. S., \& Habidin, N. fadly. (2020). Lean Healthcare Practices Improve the Patient Performance in Public Hospitals. International Journal of Academic Research in Business and Social Sciences, 10(7), 783-796.

\section{Copyright: (C) 2020 The Author(s)}

Published by Human Resource Management Academic Research Society (www.hrmars.com)

This article is published under the Creative Commons Attribution (CC BY 4.0) license. Anyone may reproduce, distribute, translate and create derivative works of this article (for both commercial and non-commercial purposes), subject to full attribution to the original publication and authors. The full terms of this license may be seen

at: http://creativecommons.org/licences/by/4.0/legalcode

\section{Vol. 10, No. 7, 2020, Pg. 783 - 796}






\title{
Lean Healthcare Practices Improve the Patient Performance in Public Hospitals
}

\author{
Maria Shazwina Tajudin, Nurul Fadly Habidin \\ Faculty of Management and Economics, Sultan Idris Education University, 35900 Tanjung Malim, \\ Perak, Malaysia.
}

\begin{abstract}
Healthcare industry is one of the industry that particular importance for development in Malaysia economy. Nowadays, this industry trying to implement the resources more effectively and efficiently. The rapidly growth in healthcare showed that the demanding in providing the services become more challenging. Lean healthcare practices is one of the principles that can minimize the waste in every procedure and can develop the task through to healthcare system. Therefore, this study explored to review the lean healthcare practices and patient performance in public hospitals. In this study, a structured model has been proposed by Structural Equation Modeling (SEM - PLS). In addition, the research hypotheses are being developed in this study.
\end{abstract}

Keywords: Lean Healthcare Practices, Patient Performance, Public Hospitals.

\section{Introduction}

In 1957 since Independence, Malaysia has been transformation in healthcare industry which interacting by public and private sector. The healthcare industry was not like a free market which care more about the profits but their main objectives especially for the staffs in hospitals is providing the efficiently services to the patients. Focusing on healthcare in terms of curative and rehabilitative at the primary, secondary and tertiary levels affected heavily in subsidized for the public healthcare. It will be more incentive to the patients and better regulation in public hospital when the cost to get the treatments to be skyrocketing.

Other than that, healthcare industry is the main sector that increase the gross domestic product (GDP) in Malaysia. It was notices that from the explosion of population growth in country (Refer Table 1.1) has been affected by the healthcare and being a part of development country which align with the other countries such as Finland. Therefore, the healthcare industry contributed to the Malaysia's economy so that the responsibility for ensuring the healthcare will be the most important in care with their health in public hospitals. In fact, the healthcare needed to be emphasized and concerned about the healthier, services and facilities. 
INTERNATIONAL JOURNAL OF ACADEMIC RESEARCH IN BUSINESS AND SOCIAL SCIENCES Vol. 10, No. 7, July, 2020, E-ISSN: 2222-6990 @ 2020 HRMARS

Table 1.1 Annual Population Growth Rate, Malaysia 2014, 2015 and 2016

\begin{tabular}{|c|c|c|c|}
\hline Year & Male & Female & Total \\
\hline 2014 & 1.7 & 1.6 & 1.6 \\
\hline 2015 & 1.5 & 1.6 & 1.5 \\
\hline 2016 & 1.5 & 1.5 & 1.5 \\
\hline
\end{tabular}

Source: Department of Statistics, Malaysia.

According to the Ministry Health Department (2017), the rapid growth in the healthcare industry around 2017 where Malaysia being as a country that choosing the healthcare as main factor. Meanwhile, the increasing expansion in the national income directly showed the positive impact on strategic investment to support the healthcare industry. Hence, the purpose of the study are to review the lean healthcare practices and patient performance and to develop the research model in relationship between lean healthcare practices and patient performance in public hospitals. In addition, there are three constructs of lean healthcare practices such as leadership, value stream mapping and continuous improvement. The three constructs of patient performance are patient satisfaction, patient retention and patient loyalty.

\section{Literature Review}

\section{An overview of Lean Healthcare Practices}

Nowadays, healthcare industries are trying to implement the lean more effectively and efficiently (Sisson \& Elshennawy, 2015). A lot of previous studies have argued that element in principles of lean can increase the efficient in healthcare (Christian et al., 2017). Much of the current literature on lean pays particular attention to make the enthusiastic among patient toward the key element of reward, communication, continuous improvement and training involvement (Chaplin et al., 2016). Often interact in lean healthcare environment especially service quality, customer care, legal issues and healthcare providers (Kondasani et al., 2015).

Other than that, it is significant impact when the healthcare system applied the lean in terms of the criteria in their job why the responsibilities among the employees and showed positive roles character (Erik \& Bozena, 2014). It is a strength when the group giving a fully supported for adapting the lean in the industry (Al-Balushi et al., 2016). According to the Balasubramanian, M., (2016), lean solve all the barriers and make the lean practices successfully recover is by the helping in healthcare industry.

Interestingly, it can be efficient way when adapting the lean healthcare practices especially in hospitals areas such as clinics, wards and administration (Laureani, et al., 2013). Several studies have revealed that it is a not just practice that acts on highest level of performance but it is an advantage in surgical work once implementing lean healthcare (Van Rossum et al., 2016). In addition, it is a new role for staffs in hospital by lean approaches to take an action about improvement process and solves the problem (Erik \& Bozena, 2014).

Other than that, the concept of lean is one of the powerful processes that affected to the organization process in the healthcare sector (Bhat, S et al., 2014). Not only manufacturing industry using the practices, nowadays the lean also useful for healthcare industry (Erik \& Bozena, 2014). 
INTERNATIONAL JOURNAL OF ACADEMIC RESEARCH IN BUSINESS AND SOCIAL SCIENCES Vol. 10, No. 7, July, 2020, E-ISSN: 2222-6990 @ 2020 HRMARS

When the hospital contribute to increase the satisfaction and quality especially among patients are likely across affected the hospitals management (Shafei, et al., 2015). Defined by Deblois \& Lepanto (2016), in terms to eliminate and accelerate the facilitated with the growth in the productivity, one of the best practices is adapting the lean healthcare in the organization.

Table 1.2 The summary of findings on lean healthcare practices

\begin{tabular}{|c|c|c|}
\hline Researcher & Year & Findings \\
\hline Sisson \& Elshennawy & 2015 & $\begin{array}{l}\text { Implement the lean more effectively and } \\
\text { efficiently }\end{array}$ \\
\hline Christian et al. & 2017 & $\begin{array}{l}\text { Element in principles of lean can increase } \\
\text { the efficient in healthcare }\end{array}$ \\
\hline Chaplin et al. & 2016 & $\begin{array}{l}\text { Lean pays particular attention to make the } \\
\text { enthusiastic among patient toward the key } \\
\text { element of reward, communication, } \\
\text { continuous improvement and training } \\
\text { involvement }\end{array}$ \\
\hline Kondasani et al. & 2015 & $\begin{array}{l}\text { Often interact in lean healthcare } \\
\text { environment especially service quality }\end{array}$ \\
\hline Erik \& Bozena, & 2014 & $\begin{array}{l}\text { It is significant impact when the healthcare } \\
\text { system applied the lean }\end{array}$ \\
\hline S. Al-Balushi et al., & 2016 & $\begin{array}{l}\text { It is a strength when the group giving a fully } \\
\text { supported for adapting the lean in the } \\
\text { industry }\end{array}$ \\
\hline Balasubramanian, M. & 2016 & $\begin{array}{l}\text { Lean solve all the barriers and make the } \\
\text { lean practices successfully recover }\end{array}$ \\
\hline Laureani, et al. & 2013 & $\begin{array}{l}\text { Be efficient way when adapting the lean } \\
\text { healthcare practices especially in hospitals } \\
\text { areas }\end{array}$ \\
\hline Van Rossum et al. & 2016 & $\begin{array}{l}\text { It is an advantage in surgical work once } \\
\text { implementing lean healthcare }\end{array}$ \\
\hline Bhat, S. et al. & 2014 & $\begin{array}{l}\text { The concept of lean is one of the powerful } \\
\text { processes that affected to the organization } \\
\text { process in the healthcare sector }\end{array}$ \\
\hline Deblois \& Lepanto & 2016 & $\begin{array}{l}\text { To eliminate and accelerate the facilitated } \\
\text { with the growth in the productivity, one of } \\
\text { the best practices is adapting the lean } \\
\text { healthcare in the organization }\end{array}$ \\
\hline
\end{tabular}

\section{Leadership}

As far as Collden et al. (2017) concerned about the leadership expressed, to create the moral of the patients in serving the best quality services is by designing the best value of vision in healthcare professionals. Strategy to lean implementation is based on the hospital managers under the main objectives created by the organizations (Nicola \& Zoe, 2013). To make any improvement like cut cost 
INTERNATIONAL JOURNAL OF ACADEMIC RESEARCH IN BUSINESS AND SOCIAL SCIENCES Vol. 10, No. 7, July, 2020, E-ISSN: 2222-6990 @ 2020 HRMARS

or do the implementation, the leadership will be as a model that gives advantage to these practices (Mazzocato et al., 2014).

The leader or manager can do their job description to be more visible in term of lean board while it display and also giving a hand to build a planner for their own style of management (Hihnala et al., 2018). There is a large volume of published studies by Chiarini \& Baccarani (2016) describing the strategy of implementing the lean in side of top management by aligning with the strong commitment in a specific deployment. Surveys such as that conducted by Collden et al. (2017) have shown that managers mostly favor to check the value of lean process that widespread the health outcomes.

However, few writers have been able to draw on any systematic research into implementation of lean where the role by a person who have the ability to be a strong leader which can transform based on the top of the organization (Julie \& Ahmad, 2015). Numerous studies have attempted to explain that the concept of leadership showed the positive significant with the implementation of lean healthcare (Van Rossum et al., 2016). However, to protect the time of actions delivered is importance to the leadership factor.

\section{Value Stream Mapping}

More recent attention has focused on the provision of the activity that complete in the right way which is called valued stream mapping (Abdelhadi \& Shakoor, 2014). Replenishment which is lean from the consumption of pull trigger through the prevailing for improvement the quality of health and value stream showed that it is one of the best solution of lean for the activity of supply chain inside of material management (Machado Guimaraes et al., 2013).

Besides that, to map the staff job description, value stream mapping considered from the staff perspective either among themselves as a staff or as a customer's (Erik \& Bozena, 2014). What we know about lean implementation in term of value stream mapping is largely based upon empirical studies that investigate how to classify what we need to be focus for improvement activities (Sisson \& Elshennawy, 2015). To reduce the error, it is considered by the implementing completed from 3 Italian hospitals which prefer the visual stream mapping in public healthcare (Chiarini \& Baccarani, 2016).

In its original incarnation, value stream mapping was suitable approach that applied in the projects of Hospitals. Due to the lack of understanding among the employees about the concept of quality, the value stream mapping supposedly abandoned to the programs of quality improvement (Brajer-Marczak \& Wiendlocha, 2018). Thus, when the implementing process showed the positive ways process, values stream mapping tools are significant to use in the healthcare industry (Cavallone et al., 2017). According to the Cheng et al. (2015), to optimize the department in the hospital especially in the operating room operation supposedly affected with the value stream mapping.

\section{Continuous Improvement}

A large and growing body of literature has investigated the continuous improvement adoption to avoid the delays, corrupted in the way of flow process and detect the interruptions which focus on 
INTERNATIONAL JOURNAL OF ACADEMIC RESEARCH IN BUSINESS AND SOCIAL SCIENCES Vol. 10, No. 7, July, 2020, E-ISSN: 2222-6990 @ 2020 HRMARS

the eliminating waste by activities of non-value-added especially among patient (Abdelhadi \& Shakoor, 2014). Recent evidence suggest that in the side of operation line must involve by the particular person especially the top management for continuous improvement in emphasized of lean creation (Collden et al., 2017). Many historians have argued that the business need to be as role model where any project can be systematic in continuous improvement further can have advantages (Chaplin et al., 2016).

Recently, in vitro studies have shown that leadership skills can some of the best approach tool to transform the culture in hospital that can increase the satisfaction among patients and stakeholder by adapting the continuous improvement (Rossum et al., 2016). It is one of the processes in continuous improvement when the managers got a high quality when they can provide the best services to satisfying the patience needed (Mosadeghrad, 2013). On the other hand, an increasing of the company revenue is the expected to contribute in term of guide the manufacturing process based on the technical aspects by the continuous improvement.

Hence, Gowen (2014) regards to reduce the wasting in the company, lean practices need to apply in healthcare industry to improve the continuous quality. It is one of the two way communication in healthcare action where more focus on the resources that can enhance the structures of the organisation further supporting to increase the improvement in each department, authority among staffs and the responsibilities of the job (Erik \& Bozena, 2014).

Table 1.3 The summary of findings on constructs of lean healthcare practices

\begin{tabular}{|l|c|c|c|}
\hline \multicolumn{1}{|c|}{ Authors } & Leadership & $\begin{array}{c}\text { Value Stream } \\
\text { Mapping }\end{array}$ & $\begin{array}{c}\text { Continuous } \\
\text { Improvement }\end{array}$ \\
\hline Collden et al. (2017) & $*$ & & $*$ \\
\hline Nicola \& Zoe (2013) & $*$ & & \\
\hline Mazzocato et al. (2014) & $*$ & & \\
\hline Hihnala et al. (2018) & $*$ & & $*$ \\
\hline Chiarini \& Baccarani (2016) & $*$ & $*$ & $*$ \\
\hline Julie \& Ahmad (2015) & $*$ & $*$ & $*$ \\
\hline Van Rossum et al., 2016 & & $*$ & \\
\hline Abdelhadi \& Shakoor, 2014 & $*$ & $*$ & \\
\hline Machado Guimaraes et al., 2013 & & $*$ & \\
\hline Erik \& Bozena, 2014 & & $*$ & \\
\hline Sisson \& Elshennawy, 2015 & & $*$ & \\
\hline Chiarini \& Baccarani, 2016 & & $*$ & $*$ \\
\hline Brajer-Marczak \& Wiendlocha, 2018 & & $*$ & $*$ \\
\hline Cavallone et al., 2017 & & $*$ & $*$ \\
\hline Cheng et al. (2015) & & $*$ & $*$ \\
\hline Chaplin et al., 2016 & & $*$ & $*$ \\
\hline Mosadeghrad, 2013 & & $*$ & $*$ \\
\hline Gowen (2014) & & $*$ & $*$ \\
\hline
\end{tabular}




\section{Healthcare in Malaysia}

There is an increasing in healthcare industry of Malaysia when the people belief that it is a serious way to provide the best quality in healthcare. In Malaysia, there are two sector in healthcare industry such as public hospitals and private hospitals. However, public hospitals is the much cheaper than getting the treatment in private hospitals because mostly it will paid by the Malaysia citizens under the taxation of income. Furthermore, public hospitals was funded by the government and it is a place that people easily to get the treatment which is more affordable.

\section{Public Hospital in Malaysia}

Public hospitals commonly called as government hospital which is owned and subsidiaries by the government. Free of charge or minimum charges given when the treatment provided by the public hospitals. This is the reasons of overcrowded happened in the government hospitals (Richard \& Nirisha, 2015). In fact, it is knows as jewels of Malaysia's healthcare industry.

\section{Patient Performance}

It is one of the reason why healthcare industry adopted the lean healthcare practices to make continuous improvement in patients' care (Lindsay et al., 2014). As mentioned by Nomie Eriksson (2017), the lean healthcare practices more performed in performance especially by the hospitals. Thus, lean is align to improve the quality which is a strategy to eliminate the waste so that any non value adding could not affect the hospital performance (Burgess \& Radnor, 2013). It also clear that to sustain the outcomes beyond lean meet positive relationship with performance (Piercy \& Rich, 2015). As well as adoption by lean healthcare practices will appropriate the changes in operation (Bamford et al., 2015).

\section{Patient Satisfactions}

Increase in the level of satisfaction could lead to perceive job among employment (Mahmoud \& Reisel, 2014). Satisfaction also makes the patient with the higher confidence in their weaknesses problem (Aradhana et al., 2012). The previous study also leads the positive impact in terms of satisfaction among patient in healthcare service quality (Asma Shabbir et al., 2016). The patient satisfaction usually measured by the received of complaints, the assessment of feedback and the repeating visit in hospitals (Burgess \& Radnor, 2013).

The patient satisfaction is significantly agreed by the Hardeep \& Shivani (2013). The effective ways to develop the quality in healthcare is by the adoption of dimension in patient satisfaction such as communication, internal environment, quality of care and administrative procedures (Manimay Ghosh, 2014). Increasing the level of service quality in hospital will indicate affected to show the highest level in satisfaction which leads the patients in behavioural intention (Muslim et al., 2013). In the facility of healthcare where the study has been shown, the upper in correlation patient satisfaction should be an important element than provide the service among doctors (Hussain \& Malik, 2016).

\section{Patient Retention}

Even the satisfaction giving the critical feedback from the patient but it is also affected to the patient retention (Dana et al., 2016). Patient retention supposedly positively driver on the role among patient 
INTERNATIONAL JOURNAL OF ACADEMIC RESEARCH IN BUSINESS AND SOCIAL SCIENCES Vol. 10, No. 7, July, 2020, E-ISSN: 2222-6990 @ 2020 HRMARS

of age (Jorma et al., 2016). Lean practices showed that focusing on implement the waste is a practices for adding value in patient retention (Preethy Nayar et al., 2016). Therefore, changes in facilitate and improve the commitment are an actions taken to influence the retention among patient (Simons et al., 2017).

\section{Patient Loyalty}

Refer from Asma Shabbir et al. (2016) showed that the impact of patient's loyalty has a positive significant with the service quality in healthcare. It is a way to improve the service quality by applying the lean practices to increase the patient loyalty in medication management (Preethy Nayar et al., 2016). Cristina \& Jose (2013) has proved that growth in service quality despite relation with the improving the quality care among patients. From a longer perspective, creation in learning of loyalty among patient have been involvement in emphasized the hospitals performance (Machado et al., 2013).

Table 1.4 The summary of findings on constructs of patient performance

\begin{tabular}{|c|c|c|}
\hline $\begin{array}{c}\text { Constructs of patient } \\
\text { performance }\end{array}$ & Authors & Findings \\
\hline \multirow[t]{8}{*}{ Patient satisfaction } & Mahmoud \& Reisel (2014) & $\begin{array}{l}\text { Level of satisfaction could lead to } \\
\text { perceive job }\end{array}$ \\
\hline & Aradhana et al. (2012) & $\begin{array}{l}\text { Satisfaction also makes the patient with } \\
\text { the higher confidence }\end{array}$ \\
\hline & Asma Shabbir et al. (2016) & $\begin{array}{l}\text { Leads the positive impact in terms of } \\
\text { satisfaction among patient in healthcare } \\
\text { service quality }\end{array}$ \\
\hline & Burgess \& Radnor (2013) & $\begin{array}{l}\text { The patient satisfaction usually } \\
\text { measured by the received of } \\
\text { complaints, the assessment of feedback } \\
\text { and the repeating visit in hospital }\end{array}$ \\
\hline & Hardeep \& Shivani (2013) & $\begin{array}{l}\text { Patient satisfaction is significantly } \\
\text { agreed }\end{array}$ \\
\hline & Manimay Ghosh (2014) & $\begin{array}{l}\text { Effective ways to develop the quality in } \\
\text { healthcare by the adoption of } \\
\text { dimension in patient satisfaction }\end{array}$ \\
\hline & Muslim et al. (2013) & $\begin{array}{l}\text { Highest level in satisfaction which leads } \\
\text { the patients in behavioral intention }\end{array}$ \\
\hline & Hussain \& Malik (2016) & $\begin{array}{l}\text { Patient satisfaction should be an } \\
\text { important element }\end{array}$ \\
\hline \multirow[t]{3}{*}{ Patient retention } & Dana et al. (2016) & $\begin{array}{l}\text { Critical feedback from the patient but it } \\
\text { is also affected to the patient retention }\end{array}$ \\
\hline & Jorma et al. (2016) & $\begin{array}{l}\text { Patient retention supposedly positively } \\
\text { driver on the role among patient of age }\end{array}$ \\
\hline & Preethy Nayar et al. (2016) & $\begin{array}{l}\text { On implement the waste is a practices } \\
\text { for adding value in patient retention }\end{array}$ \\
\hline
\end{tabular}


INTERNATIONAL JOURNAL OF ACADEMIC RESEARCH IN BUSINESS AND SOCIAL SCIENCES Vol. 10, No. 7, July, 2020, E-ISSN: 2222-6990 @ 2020 HRMARS

\begin{tabular}{|l|l|l|}
\hline Patient loyalty & Simons et al. (2017) & $\begin{array}{l}\text { Changes in facilitate and improve the } \\
\text { commitment are an actions taken to } \\
\text { influence the retention among patient }\end{array}$ \\
\cline { 2 - 4 } & Asma Shabbir et al. (2016) & $\begin{array}{l}\text { Patient's loyalty has a positive } \\
\text { significant with the service quality in } \\
\text { healthcare }\end{array}$ \\
\hline Cristina \& Jose (2013) & $\begin{array}{l}\text { Applying the lean practices to increase } \\
\text { the patient loyalty in medication } \\
\text { management }\end{array}$ \\
\hline & $\begin{array}{l}\text { Growth in service quality despite } \\
\text { relation with the improving the quality } \\
\text { care among patients }\end{array}$ \\
\hline Machado et al. (2013) & $\begin{array}{l}\text { Learning of loyalty among patient have } \\
\text { been involvement in emphasized the } \\
\text { hospitals performance }\end{array}$ \\
\hline
\end{tabular}

\section{Research Hypotheses}

$\mathrm{H1}$ : The lean healthcare practices have significant relationship on patient performance.

Jorma et al. (2016) said that to achieve being the potential in lean concepts is by managing the care and patient systematically. In addition, Pattanayak et al. (2017) also showed that patient satisfaction is direct related with the lean practices. In the same way by Psomas et al. (2014), the practices also become demanding to make the customer satisfaction with the services and it is related with the level of customer satisfaction (Adjei \& Mensah, 2016). Previous studies highlight a range of positive between performance and lean healthcare (Azyan et al., 2017). It is also clear that there are positive relationship between lean practices and organizational performance (Chavez, et al., 2013).

\section{Research Methodology}

The methodology of this study is using the sampling method by distributed questionnaire in Public hospitals of Malaysian Healthcare industry. In this study also, will focus on distributed questionnaire to the staffs and the data received from the respondents will analyze by adopted of statistical technique Structural Equation Modelling (SEM - PLS) to perform the outcome from the survey. In addition, to test the construct of reliability, validity and measurement were adopted by the Exploratory Factor Analysis.

\section{A Proposed Research Model}

In this study, the main objective is to identify the relationship between lean healthcare practices and patient performance in public hospitals. Reviewed the literature, many researchers had examined the lean healthcare practices and patient performance. Hence, a proposed research model as followed in figure 1. 


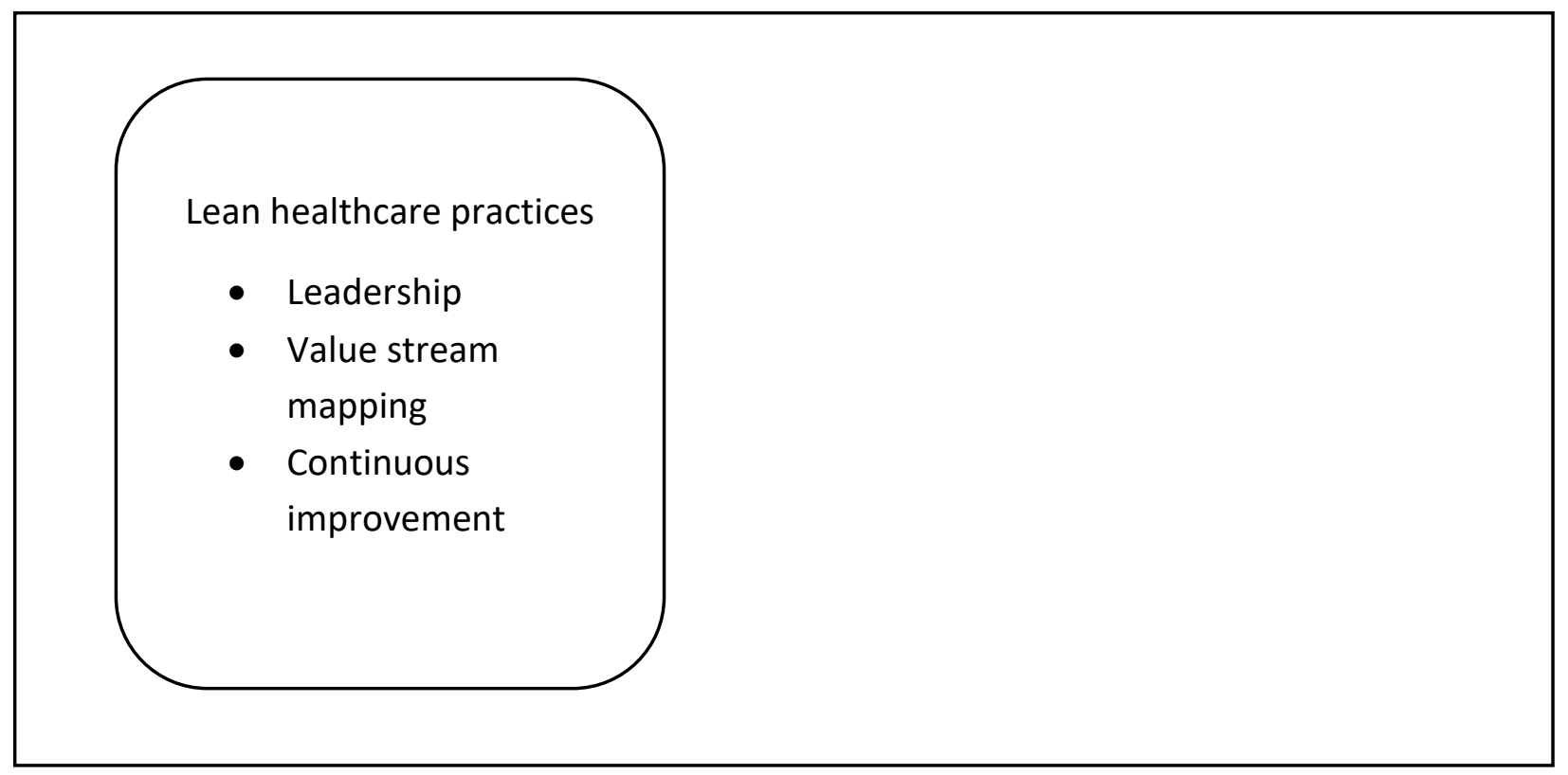

\section{Conclusion and Future Research}

To improve the patient performance in public hospitals, these practices should be adapting to realize sustainable (Simons, et.al, 2017). From a daily practices, it can be effectively develop and ability to adapt the lean healthcare practices in public hospitals (Pamela et.al, 2014). Ultimately, research model has been proposed and being developed by the research hypotheses. Designing of questionnaire is the next step of this study and it will use for collecting the data by the pilot study in public hospitals of Malaysian healthcare industry. Hopefully, the findings of the study can be useful and benefits not only focusing on researcher in academic line but also can be references to the hospitals in Malaysia.

\section{Acknowledgement}

The researcher would like to acknowledge the main supervisor Dr Nurul Fadly Habidin, UPSI.

\section{Corresponding Author}

Maria Shazwina Binti Tajudin

Department Management and Economics, University Pendidikan Sultan Idris 35600 Tanjung Malim, Perak, Malaysia 
INTERNATIONAL JOURNAL OF ACADEMIC RESEARCH IN BUSINESS AND SOCIAL SCIENCES

Vol. 10, No. 7, July, 2020, E-ISSN: 2222-6990 @ 2020 HRMARS

\section{References}

Abdelhadi, A., \& Shakoor, M. (2014). Studying the efficiency of inpatient and outpatient pharmacies using lean manufacturing. Leadership in Health Services, 27(3), 255-267. https://doi.org/10.1108/LHS-04-2013-0019

Abdelhadi, A., \& Shakoor, M. (2014). Studying the efficiency of inpatient and outpatient pharmacies using lean manufacturing. Leadership in Health Services, 27(3), 255-267. https://doi.org/10.1108/LHS-04-2013-0019

Adjei, E., \& Mensah, M. (2016). Adopting total quality management to enhance service delivery in medical records: Exploring the case of the Korle-Bu Teaching Hospital in Ghana. Records Management Journal, 26(2), 140-169. https://doi.org/10.1108/RMJ-01-2015-0009

Azyan, A. Z. H., Pulakanam, V., \& Pons, D. (2017). Success factors and barriers to implementing lean in the printing industry: A case study and theoretical framework. Journal of Manufacturing Technology Management, 28(4), 458-484. https://doi.org/10.1108/JMTM-05-2016-0067

Al-Balushi, S., Sohal, A. S., Singh, P. J., Hajri, A. Al, Farsi, Y. M. A., \& Abri, R. Al. (2014). Readiness factors for lean implementation in healthcare settings - a literature review. Journal of Health, Organisation and Management, 28(2), 135-153. https://doi.org/10.1108/JHOM-04-2013-0083

Bhargava, A., Thakur, A., Mishra, B., Taneja, J., Dogra, V., Loomba, P. (2012). Patient satisfaction survey of microbiological tests done in G.B. Pant Hospital. International Journal of Health Care Quality Assurance Article information: Nternational Journal of Health Care Quality Assurance, 20, 572-584. https://doi.org/10.1108/09526860710819440

Asma Shabbir, Shahab Alam Malik, Shujah Alam Malik (2016). Measuring Patients' Healthcare Service Quality Perceptions, Satisfaction, And Loyalty in Public and Private Sector Hospitals In Pakistan. International Journal of Quality \& Reliability Management, 33:5, 538-557

Balasubramanian, M. (2016). Total Quality Management [TQM] in the Healthcare Industry Challenges, Barriers and Implementation Developing a Framework for TQM Implementation in a Healthcare Setup. Science Journal of Public Health, 4(4), 271. https://doi.org/10.11648/j.sjph.20160404.11

Bamford, D., Forrester, P., Dehe, B., \& Leese, R. G. (2015). Partial and iterative lean implementation: Two case studies. International Journal of Operations and Production Management, 35(5), 702727. https://doi.org/10.1108/IJOPM-07-2013-0329

Bhat, S., Gijo, E. V., \& Jnanesh, N. A. (2014). Application of Lean Six Sigma methodology in the registration process of a hospital. International Journal of Productivity and Performance Management, 63(5), 613-643. https://doi.org/10.1108/IJPPM-11-2013-0191

Brajer-Marczak, R., \& Wiendlocha, A. (2018). Lean Management Concept in Hospital Management Possibilities and Limitations. Management Sciences, 23(1), 4-12.

https://doi.org/10.15611/ms.2018.1.01

Burgess, N., \& Radnor, Z. (2013). Evaluating Lean in healthcare. International Journal of Health Care Quality Assurance, 26(3), 220-235. https://doi.org/10.1108/09526861311311418

Burgess, N., \& Radnor, Z. (2013). Evaluating Lean in healthcare. International Journal of Health Care Quality Assurance, 26(3), 220-235. https://doi.org/10.1108/09526861311311418

Carter, J. C., and Silverman, F. N. (2016). Using HCAHPS data to improve hospital care quality. The TQM Journal, Vol. 28 No. 6, pp. 974-990. 
INTERNATIONAL JOURNAL OF ACADEMIC RESEARCH IN BUSINESS AND SOCIAL SCIENCES

Vol. 10, No. 7, July, 2020, E-ISSN: 2222-6990 @ 2020 HRMARS

Cavallone, M., Magno, F., \& Zucchi, A. (2017). Improving service quality in healthcare organisations through geomarketing statistical tools. TQM Journal, 29(5), 690-704. https://doi.org/10.1108/TQM-12-2016-0104

Chaplin, L., Heap, J., \& O'Rourke, S. T. J. (2016). Could "Lean Lite" be the cost effective solution to applying lean manufacturing in developing economies? International Journal of Productivity and Performance Management, 65(1), 126-136. https://doi.org/10.1108/IJPPM-02-2015-0034

Chaplin, L., Heap, J., \& O’Rourke, S. T. J. (2016). Could "Lean Lite" be the cost effective solution to applying lean manufacturing in developing economies? International Journal of Productivity and Performance Management, 65(1), 126-136. https://doi.org/10.1108/IJPPM-02-2015-0034

Chavez, R., Gimenez, C., Fynes, B., Wiengarten, F., and Yu, W. (2013). Internal lean practices and operational performance: the contingency perspective of industry clockspeed. International Journal of Operations \& Production Management, Vol. 33 No. 5, pp. 562-588

Cheng, S. Y., Bamford, D., Papalexi, M., \& Dehe, B. (2015). Improving access to health Services Challenges in lean application. International Journal of Public Sector Management, 28(2), 121135. https://doi.org/10.1108/IJPSM-05-2014-0066

Chiarini, A., \& Baccarani, C. (2016). TQM and lean strategy deployment in Italian hospitals: Benefits related to patient satisfaction and encountered pitfalls. Leadership in Health Services, 29(4), 377-391. https://doi.org/10.1108/LHS-07-2015-0019

Collden, C., Gremyr, I., Hellstrom, A., \& Sporraeus, D. (2017). A value-based taxonomy of improvement approaches in healthcare. Journal of Health, Organisation and Management, 31(4), 445-458. https://doi.org/10.1108/JHOM-08-2016-0162

Collden, C., Gremyr, I., Hellstrom, A., \& Sporraeus, D. (2017). A value-based taxonomy of improvement approaches in healthcare. Journal of Health, Organisation and Management, 31(4), 445-458. https://doi.org/10.1108/JHOM-08-2016-0162

Collden, C., Gremyr, I., Hellstrom, A., \& Sporraeus, D. (2017). A value-based taxonomy of improvement approaches in healthcare. Journal of Health, Organisation and Management, 31(4), 445-458. https://doi.org/10.1108/JHOM-08-2016-0162

Johnson, D. M., Russell, R. S., White, S. W. (2016). Perceptions of care quality and the effect on patient satisfaction. International Journal of Quality \& Reliability Management, Vol. 33 Issue: 8, pp.12021229, https://doi.org/10.1108/IJQRM-08-2015-0121

Deblois, S., \& Lepanto, L. (2016). Lean and Six Sigma in acute care: a systematic review of reviews. International Journal of Health Care Quality Assurance, 29(2), 192-208. https://doi.org/10.1108/IJHCQA-05-2014-0058

Drotz, E., Poksinska, B. (2014). Lean in healthcare from employees' perspectives. Journal of Health Organization and Management, Vol. 28 Issue: 2, pp.177-195, https://doi.org/10.1108/JHOM03-2013-0066

Eriksson, N. (2017). Hospital management from a high reliability organizational change perspective: A Swedish case on Lean and Six Sigma. International Journal of Public Sector Management, 30(1), 67-84. https://doi.org/10.1108/IJPSM-12-2015-0221.

Ali, F., Amin, M., Cobanoglu, C. (2016). An Integrated Model of Service Experience, Emotions, Satisfaction, and Price Acceptance: An Empirical Analysis in the Chinese Hospitality Industry. Journal of Hospitality Marketing \& Management, 25:4, 449-475.

Gowen, C. (2014). Contrasting Continuous Quality Improvement, Six Sigma, and Lean Management for Enhanced Outcomes in US Hospitals. American Journal of Business, 27(2), 133-153 
INTERNATIONAL JOURNAL OF ACADEMIC RESEARCH IN BUSINESS AND SOCIAL SCIENCES

Vol. 10, No. 7, July, 2020, E-ISSN: 2222-6990 @ 2020 HRMARS

Chahal, H., \& Mehta, S. (2013). Modeling patient satisfaction construct in the Indian health care context. International Journal of Pharmaceutical and Healthcare Marketing, Vol. 7 Issue: 1, pp.75-92, https://doi.org/10.1108/17506121311315445.

Hihnala, S., Kettunen, L., Suhonen, M., \& Tiirinki, H. (2018). The Finnish healthcare services lean management: Health services managers' experiences in a special health care unit. Leadership in Health Services, 31(1), 17-32. https://doi.org/10.1108/LHS-03-2017-0020.

Hussain, M., \& Malik, M. (2016). Prioritizing lean management practices in public and private hospitals. Journal of Health, Organisation and Management, 30(3), 457-474. https://doi.org/10.1108/JHOM-08-2014-0135.

Jorma, T., Tiirinki, H., Bloigu, R., \& Turkki, L. (2016). LEAN thinking in Finnish healthcare. Leadership in Health Services, 29(1), 9-36. https://doi.org/10.1108/LHS-08-2015-0021.

Jorma, T., Tiirinki, H., Bloigu, R., \& Turkki, L. (2016). LEAN thinking in Finnish healthcare. Leadership in Health Services, 29(1), 9-36. https://doi.org/10.1108/LHS-08-2015-0021.

Kondasani, R. K. R., \& Panda, R. K. (2015). Customer perceived service quality, satisfaction and loyalty in Indian private healthcare. International Journal of Health Care Quality Assurance, 28(5), 452467. https://doi.org/10.1108/IJHCQA-01-2015-0008.

Laureani, A., Brady, M., \& Antony, J. (2013). Applications of Lean Six Sigma in an Irish hospital. Leadership in Health Services, 26(4), 322-337. https://doi.org/10.1108/LHS-01-2012-0002.

Lindsay, C., Commander, J., Findlay, P., Bennie, M., Corcoran, D. E., and Van Der Meer, R. (2014). Lean new technologies and employment in public health services: employees' experiences in the National Health Service. The International Journal ofHuman Resource Management, Vol. 25 No. 21, pp. 2941-2956.

Guimaraes, M. C., Carvalho, C. de J., \& Maia, A. (2013). Vendor managed inventory (VMI): evidences from lean deployment in healthcare. Strategic Outsourcing: An International Journal, 6(1), 8-24. https://doi.org/10.1108/17538291311316045

Guimaraes, M. C., Carvalho, C. de J., \& Maia, A. (2013). Vendor managed inventory (VMI): evidences from lean deployment in healthcare. Strategic Outsourcing: An International Journal, 6(1), 8-24. https://doi.org/10.1108/17538291311316045

Mahmoud, A. B., \& Reisel, W. D. (2014). Relating patient satisfaction to nurses' job satisfaction, job security, and obedience OCBs. International Journal of Pharmaceutical and Healthcare Marketing, 8(1), 47-61. https://doi.org/10.1108/IJPHM-01-2013-0001

Ghosh, M. (2014). Measuring patient satisfaction: An empirical study in India. Leadership in Health Services, Vol. 27 Issue: 3, pp.240-254, https://doi.org/10.1108/LHS-06-2013-0027

Mazzocato, P., Thor, J., Bäckman, U., Brommels, M., Carlsson, J., Jonsson, F., Hagmar, M., \& Savage, C. (2014). Complexity complicates lean: Lessons from seven emergency services. Journal of Health, Organisation and Management, 28(2), 266-288. https://doi.org/10.1108/JHOM-032013-0060

Miller, R., \& Chalapati, N. (2015). Utilizing lean tools to improve value and reduce outpatient wait times in an indian hospital. Leadership in Health Services, 28(1), 57-69. https://doi.org/10.1108/LHS-01-2014-0001

Mosadeghrad, A. M. (2013). Healthcare service quality: Towards a broad definition. International Journal of Health Care Quality Assurance, 26(3), 203-219. https://doi.org/10.1108/09526861311311409 
INTERNATIONAL JOURNAL OF ACADEMIC RESEARCH IN BUSINESS AND SOCIAL SCIENCES

Vol. 10, No. 7, July, 2020, E-ISSN: 2222-6990 @ 2020 HRMARS

Nayar, P., Ojha, D., Fetrick, A., \& Nguyen, A. T. (2016). Applying Lean Six Sigma to improve medication management. International Journal of Health Care Quality Assurance, 29(1), 16-23. https://doi.org/10.1108/IJHCQA-02-2015-0020

Pattanayak, D., Koilakuntla, M., \& Punyatoya, P. (2017). Investigating the influence of TQM, service quality and market orientation on customer satisfaction and loyalty in the Indian banking sector. International Journal of Quality and Reliability Management, 34(3), 362-377. https://doi.org/10.1108/IJQRM-04-2015-0057

Piercy, N., \& Rich, N. (2015). The relationship between lean operations and sustainable operations. International Journal of Operations and Production Management, 35(2), 282-315. https://doi.org/10.1108/IJOPM-03-2014-0143.

Psomas, E., Vouzas, F., \& Kafetzopoulos, D. (2014). Quality management benefits through the "soft" and "hard" aspect of TQM in food companies. TQM Journal, 26(5), 431-444. https://doi.org/10.1108/TQM-02-2013-0017.

Shafei, I., Walburg, J. A., \& Taher, A. F. (2015). Healthcare service quality: what really matters to the female patient? International Journal of Pharmaceutical and Healthcare Marketing, 9(4), 369391. https://doi.org/10.1108/IJPHM-05-2014-0028

Simons, P., Backes, H., Bergs, J., Emans, D., Johannesma, M., Jacobs, M., Marneffe, W., \& Vandijck, D. (2017). The effects of a lean transition on process times, patients and employees. International Journal of Health Care Quality Assurance, 30(2), 103-118. https://doi.org/10.1108/IJHCQA-082015-0106.

Sisson, J., \& Elshennawy, A. (2015). Achieving success with Lean: An analysis of key factors in Lean transformation at Toyota and beyond. International Journal of Lean Six Sigma, 6(3), 263-280. https://doi.org/10.1108/IJLSS-07-2014-0024.

Sisson, J., \& Elshennawy, A. (2015). Achieving success with Lean: An analysis of key factors in Lean transformation at Toyota and beyond. International Journal of Lean Six Sigma, 6(3), 263-280. https://doi.org/10.1108/IJLSS-07-2014-0024.

Van Rossum, L., Aij, K. H., Simons, F. E., Van der Eng, N., \& Ten Have, W. D. (2016). Lean healthcare from a change management perspective: The role of leadership and workforce flexibility in an operating theatre. Journal of Health, Organisation and Management, 30(3), 475-493. https://doi.org/10.1108/JHOM-06-2014-0090.

Yapa, S. (2012). Total quality management in Sri Lankan service organizations. TQM Journal, 24(6), 505-517. https://doi.org/10.1108/17542731211270070. 